\title{
CITRA KAWASAN STRATEGIS NASIONAL CEKUNGAN \\ BANDUNG MELALUI INSTAGRAM PADA PENGGUNA HASHTAG \#EXPLOREBANDUNG
}

\author{
Rangga Putera Perdana, Maylanny Christin, dan Ruth Mei Ulina Malau \\ Universitas Telkom
}

\begin{abstract}
ABSTRAK
Penelitian ini berjudul "Citra Kawasan Strategis Nasional (KSN) Cekungan Bandung Melalui Instagram (Studi Deskriptif pada Pengguna Hashtag \#explorebandung). Alasan mengambil judul tersebut karena penggunaan hashtag \#explorebandung yang sudah mencapai jutaan foto dengan keterkaitannya pada citra KSN Cekungan Bandung itu sendiri. Penelitian ini difokuskan pada citra KSN Cekungan Bandung melalui perspektif pengguna hashtag \#explorebandung di Instagram. Tujuan penelitian ini adalah untuk mendeskripsikan citra KSN Cekungan Bandung dari sisi pengguna hashtag \#explorebandung, dengan menggunakan ragam informan, baik itu warga asli Bandung ataupun wisatawan yang berkunjung ke Bandung. Metode penelitian yang digunakan adalah penelitian kualitatif dengan pendekatan deskriptif menggunakan teknik purposive sampling. Jenis data yang digunakan adalah data primer melalui wawancara mendalam dan observasi. Data yang diperoleh kemudian dianalisis dengan menggunakan teknik analisis data model Miles dan Huberman. Dapat disimpulkan berdasarkan hasil penelitian ini menunjukkan bahwa citra KSN Cekungan Bandung dilihat dari sudut pandang pengguna hashtag \#explorebandung ialah bagus dan positif. Selain itu, bentuk kegiatan yang dilakukan oleh pengguna hashtag \#explorebandung dalam keterkaitannya akan citra KSN Cekungan Bandung adalah dengan mengikuti kegiatan Worldwide Instameet (WWIM) yang diselenggarakan oleh komunitas Explorebandung.
\end{abstract}

Kata-kata kunci: Citra, citra tempat, media sosial, instagram, pengguna hashtag

\section{THE IMAGE OF THE BANDUNG NATIONAL STRATEGIC AREAS BASIN THROUGH \#EXPLOREBANDUNG INSTAGRAM HASHTAG USER}

\begin{abstract}
This research entitled "The Image of the National Strategic Areas Bandung Basin Through Instagram \#explorebandung Hashtag User". The reason took the title because the use of the hashtag \#explorebandung that has reached millions of photos with relation to the Bandung Basin (KSN) image itself. This study focused on the image of Bandung Basin (KSN) via a user perspective \#explorebandung hashtag on Instagram. The purpose of this study was to describe the Bandung Basin (KSN) image from the user side hashtag \# explorebandung, using a variety of informants, both the original Bandung residents or tourists visiting Bandung. The method used is a qualitative study with a descriptive approach using purposive sampling technique. The data used is primary data through in-depth interviews and observation. Data were analyzed using data analysis techniques Miles and Huberman's model. It can be concluded based on the results of this study indicate that the image KSN Bandung Basin viewed from the standpoint of users hashtag \#explorebandung is good and positive. In addition, the form of the activities that performed by the user in relation \#explorebandung hashtag and image Bandung Basin (KSN) is to attend the activities of Worldwide Instameet (WWIM) that held by Explorebandung community.
\end{abstract}

Keywords: Image, place image, social media, instagram, hashtag user

Korespondensi: Rangga Putera Perdana, S.I.Kom. Program Studi Ilmu Komunikasi, Fakultas Komunikasi dan Bisnis, Universitas Telkom, Jalan Telekomunikasi No. 1, Bandung, Jawa Barat. Email: halorangga@gmail.com 


\section{PENDAHULUAN}

Internet merupakan salah satu bentuk perkembangan teknologi di bidang penyebaran informasi dan data. Internet ini sendiri dikatakan sebagai new media karena keberadaannya kini sudah dapat disetarakan dengan media-media konvensional lainnya. Dikatakan demikian karena dalam Internet dapat terkandung semua hal yang terkandung pada media konvensional, seperti audio maupun visual, dalam tujuannya yaknisebagaipenyampaipesan. Salahsatubentuk pengembangannya adalah keberadaan media sosial Instagram. Instagram merupakan sebuah media sosial yang bergerak di bidang visual, yang memungkinkan penggunanya berbagi foto maupun video kepada orang lain. Instagram sendiri memberikan banyak kemudahan bagi para penggunanya untuk mengeksplorasi keberadaan media sosial tersebut. Sebutlah fitur filter foto guna memberikan kesan artistik pada foto yang akan diunggah, hingga fitur tagging yang berfungsi untuk menandai seseorangdalam kasus ini ialah akun Instagram orang tersebut - pada sebuah foto yang memang berkaitan dengan orang tersebut. Salah satu fitur lainnya adalah hadirnya fitur hashtag (\#). Fitur ini sendiri memungkinkan pengguna untuk mengklasifikasikan foto-foto yang mereka unggah serta mencari klasifikasi tersebut.

Hashtag \#explorebandung merupakan sebuah hashtag yang berfungsi untuk mengklasifikasikan tempat-tempat baru, unik dan menarik dari seluruh penjuru wilayah Bandung. Jika \#kulinerbandung lebih terspesifikasi sebagai hashtag kuliner, \#explorebandung memposisikan dirinya sebagai hashtag jelajah, petualang, eksplorasi dan jalan-jalan. Hal tersebut terlihat dari penggunaan kata-kata explore yang dialihbahasakan berarti menjelajah ataupun eksplorasi.

Teknologi pada zaman sekarang dapat memberikan dampak yang begitu luar biasa bagi banyak hal, salah satunya adalah keberadaan suatu tempat pada satu wilayah. Ini dibuktikan dengan popularitas KSN Cekungan Bandung semenjak adanya media baru Instagram dan keberadaan akun serta hashtag \#explorebandung. Tempat-tempat baru bermunculan ke publik, seperti Tebing Keraton, Bukit Moko, Lawangwangi Artspace, Stone Garden dll. Tempat-tempat tersebut muncul dan eksis dikalangan masyarakat berkat adanya teknologi bernama Instagram dengan fitur pengklasifikasiannya yang bernama hashtag. Lantas fitur tersebut selanjutnya digunakan oleh pemuda/i kreatif Bandung untuk mempromosikan tempat-tempat tersebut sekaligus meningkatkan citra Bandung sebagai salah satu destinasi wisata di Jawa Barat.

Kota Bandung merupakan salah satu wilayah yang termasuk ke dalam KSN Cekungan Bandung. KSN merupakan kepanjangan dari Kawasan Strategis Nasional yang memiliki pengertian yaitu wilayah yang penataan ruangnya diprioritaskan karena mempunyai pengaruh yang sangat penting secara nasional terhadap kedaulatan negara, pertahanan dan keamanan negara, ekonomi, sosial, budaya dan/atau lingkungan, termasuk wilayah yang ditetapkan sebagai warisan dunia (Ditjen Mineral dan Batubara, 2008). Menurut Peraturan Pemerintah Republik Indonesia No. 26 Tahun 2008 Lampiran X tentang Penetapan Kawasan Strategis Nasional, Kawasan Cekungan Bandung masuk ke dalam kawasan yang mendapat perhatian khusus untuk dikembangkan lebih lanjut. Ada lima kota/ kabupaten yang menempati wilayah cekungan Bandung itu sendiri, yaitu Kota Bandung, Kota Cimahi, Kabupaten Bandung Barat, Kabupaten Bandung Selatan dan Kabupaten Sumedang. Seperti dilansir pada laman Tempo, para otoritas kelima wilayah tersebut sudah sepakat akan keberlanjutan Peraturan Pemerintah tersebut ke dalam bentuk Peraturan Presiden guna mensinergikan proyek pengembangan yang telah disepakati (Fikri, 2015).

Dengan adanya peraturan tersebut, tercipta kesinambungan antar wilayah di Cekungan Bandung dalam mengembangkan potensi pariwisata yang mereka miliki masing-masing. Cekungan Bandung beruntung memiliki wilayah-wilayah seperti Kota Bandung, Kabupaten Bandung Barat, Kabupaten Bandung, Kota Cimahi dan Kabupaten Sumedang dalam lingkup geografisnya, karena memang kawasan ini kaya akan potensi-potensi pariwisata untuk dikembangkan lebih lanjut. Contohnya seperti kawasan hutan Cikole-Jayagiri, perkebunan teh di Pangalengan dan Kawah Puth yang berada di Kabupaten Bandung, Taman Hutan Raya Ir. H. Juanda, Alun-Alun Kota Bandung, kawasan Braga dan Bukit Moko yang berada 
di Kota Bandung, Stone Garden yang berada di Padalarang, ataupun Curug Cimahi yang akhir-akhir ini menjadi buah bibir dikalangan wisatawan lokal. Beberapa tempat tersebut terpisah di beberapa wilayah Cekungan Bandung, namun dengan adanya hashtag \# explorebandung didukung dengan keluarnya PP serta perpres nanti, akan membuat citra kawasan ini semakin kuat akan daya tarik pariwisatanya.

Citra ini tentu akan berpengaruh pada ketertarikan investor dalam perihal menanam investasinya pada sebuah kota. Jika sebuah wilayah memiliki citra yang buruk-baik itu dari penampilan fisik maupun kualitas orang-orang yang bekerja dibelakang wilayah tersebut - tentu investor akan berpikir dua kali untuk menanam investasi di wilayah tersebut. Pemandangan yang berbeda akan terjadi jika sebuah wilayah memiliki citra yang baik, tentu investor tidak akan berpikir panjang untuk menanam investasi di wilayah tersebut, sehingga roda perekonomian wilayah tersebut dapat terus berjalan. Disini terlihat bahwa ternyata citra turut memberikan peranan yang penting dalam membangun infrastruktur sebuah wilayah.

Citra sebuah wilayah terbentuk sebagai hasil interaksi warga dengan lingkungannya. Interaksi tersebut bisa bersifat tidak langsung berkat adanya media. Media disini dibagi menjadi dua jenis, yaitu media yang dikontrol pengelola wilayah (website, video promosi, brosur, dll) dan media yang tidak dikontrol oleh pengelola wilayah (media sosial, televisi, surat kabar, dll). Dalam kenyataannya, citra yang lahir dalam media yang tidak dikontrol oleh pengelolanya bisa berdampak lebih besar. Seperti contoh kasus Jakarta dalam citranya di media. Jakarta memiliki jumlah berita sebanyak 1557 berita dengan pembagian tone berita positif sebanyak 621 berita, berita negatif sebanyak 838 berita dan berita netral sebanyak 98 berita. Pada kasus ini, berita diambil menjadi objek dalam melihat citra di media, karena dalam berita-lah seseorang dapat melihat identitas dari suatu wilayah. Dilihat dari perbandingan tone berita tersebut, bisa disimpulkan bahwa Jakarta merupakan wilayah yang kaya akan citra. Namun, citra yang dominan adalah citra yang buruk, terutama dalam aspek kriminalitas, kemacetan, kecelakaan dan bencana. Terlihat bahwa media yang tidak dikontrol dapat memberikan efek yang tidak kecil bagi wilayah/ kota tersebut, baik itu efek negatif maupun positif.

Sama halnya dengan Jakarta, wilayahwilayah di Cekungan Bandung-pun tidak terlepas dari masalah-masalah yang sama. Sebaliknya, otoritas wilayah yang berada di lingkungan KSN Cekungan Bandung, terbantu oleh adanya Instagram ini dalam hal meningkatkan citra wilayahnya. Ini dapat dilihat dari jumlah postingan foto yang diunggah di Instagram, serta sudut-sudut pengambilan foto yang menampilkan keindahan dari wilayah-wilayah yang terdapat di kawasan Cekungan Bandung. Dengan melihat jumlah pengguna media sosial tertinggi di Jawa Barat tentu masyarakatnya sudah paham akan keberadaan Instagram yaitu sebagai media berbagi informasi dalam bentuk foto ataupun video, walaupun ternyata penggunaannya dapat jauh lebih berarti dibandingkan hanya dengan mengunggah sebuah foto, yakni meningkatkan citra wilayah Cekungan Bandung itu sendiri. Jumlah tersebut-pun belum dihitung dengan para wisatawan yang sengaja datang ke Bandung untuk berwisata. Hal ini seperti efek domino yang dihasilkan dari keberadaan citra dalam media yang tidak dikontrol. Tentu dalam waktu yang tidak lama, penggunaan hashtag explorebandung menjadi sebuah fenomena. Adapun yang menjadi fokus penelitian ini adalah: (1) Apa bentuk kegiatan yang dilakukan oleh pengguna hashtag \#explorebandung dalam keterkaitannya mengenai citra KSN Cekungan Bandung di Instagram?, (2) Bagaimana citra KSN Cekungan Bandung oleh pengguna hashtag \#explorebandung?, dan (3) Tempat mana sajakah yang sering dijadikan objek foto oleh pengguna hashtag \# explorebandung di Instagram?

Adapun hal yang menjadi tujuan dari penelitian ini, yaitu: (1) Mengetahui bentuk kegiatan yang dilakukan oleh pengguna hashtag \# explorebandung dalam keterkaitannyamengenai citra KSN Cekungan Bandung di Instagram, (2) Mengetahui citra KSN Cekungan Bandung oleh pengguna hashtag \#explorebandung mengenai, dan (3) Mengetahui tempat yang sering dijadikan objek foto oleh pengguna hashtag \# explorebandung di Instagram.

Menurut West dan Turner (2008: 5), komunikasi adalah proses sosial dimana individu-individu menggunakan simbol-simbol untuk menciptakan dan menginterpretasikan makna dalam lingkungan mereka. Tujuan-tujuan 
dari komunikasi, yaitu, (1) Mengubah sikap (to change the attitude), (2) Mengubah opini/ pendapat/pandangan (to change the opinion), (3) Mengubah perilaku (to change behaviour), dan (4) Mengubah masyarakat (to change the society).

Internet merupakan sistem jaringan global yang menghubungkan seluruh komputer di seluruh dunia. Namun begitu, ada beberapa perbedaan dari media baru dengan media lama atas apa yang dilakukan Internet dalam menggabungkan radio, film dan televisi serta menyebarkannya melalui teknologi 'tekan'. Berbagai macam hal dapat kita lakukan didalam Internet. Semua seolah menjadi samar jika berkaitan dengan Internet. Hampir semua orang di planet ini yang memiliki komputer dapat mengunjungi Internet. Dengan beberapa kali mengklik tombol mouse, kita akan memasuki lautan informasi dan hiburan di seluruh dunia. Kendati demikian, Internet ini bersifat interaktif. Internet memiliki kapasitas untuk memampukan orang berkomunikasi, dan bukan hanya sekedar menerima pesan belaka, dan mereka bisa melakukannya secara real time (Vivian, 2008: 262).

Istilah media baru sampai sekarang masih menimbulkan perdebatan dikalangan ilmuwan dan peneliti yang berkecimpung di bidang ini. Kesan awal yang muncul dari konsep media baru ini sering diartikan sebagai media interaktid yang berbahan dasar komputer. Pengertian media baru kemudian yang selanjutnya memberikan cakupan yang lebih luas dijelaskan oleh Croteau (2003: 12) bahwa media baru muncul akibat inovasi teknologi dalam bidang media yang meliputi televisi kabel, satelit, teknologi fiber optik dan komputer. Dengan teknologi seperti itu, pengguna bisa secara interaktif membuat pilihan serta menyediakan respon produk media secara beragam.

Situs jejaring sosial dalam bahasa Inggris disebut dengan social network ataupun social media, yang merupakan sebuah web berbasis pelayanan yang memungkinkan penggunanya untuk membuat profil, melihat daftar pengguna yang tersedia, serta mengundang atau menerima teman untuk bergabung dalam situs tersebut (Somad, 2014: 231).

Citramerupakan serangkaian pengetahuan, pengalaman, perasaan (emosi) dan penilaian yang diorganisasikan dalam sistem kognisi manusia; atau pengetahuan pribadi yang sangat diyakini kebenerannya (Ardianto, 2011: 98). Citra tidak melekat dalam diri seorang individu maupun organisasi saja, namun setiap benda di dunia ini memiliki citra, bahkan bagi yang tak bernyawa-pun memiliki citra. Tentu hal tersebut akan memiliki perbedaan pemahaman dalam ranah ilmu pengetahuan. Citra dapat diartikan sebagai kata benda; sebagai gambaran yang dimiliki oleh orang banyak mengenai pribadi, perusahaan maupun produk; atau sebagai bayangan visual yang ditimbulkan oleh sebuah kata, frase atau kalimat.

Kenneth Boulding mengartikan citra sebagai "The image is built up as a result of all past experience of the possessor of the image" yang artinya citra dibentuk sebagai hasil pengalaman masa lalu (Boulding, 1956: 6). Boulding membagi citra menjadi sepuluh klasifikasi yang berbeda, yaitu (1) Citra ruang, (2) Citra waktu, (3) Citra rasional, (4) Citra perorangan, (5) Citra nilai, (6) Citra emosional, (7) Citra kesadaran atau ketidaksadaran, (8) Citra keyakinan atau ketidakyakinan, (9) Citra dalam dimensii realitas dan bukan realitas bahwa citra berkaitan dengan dunianya dengan sesuatu diluar realitas, serta (10) Citra yang bersifat umum, yaitu citra pribadi yang sesuai dengan citra yang ditunjukkan oleh kehendak orang lain (Ardianto, 2011: 98). Lebih lanjut, citra adalah peta tentang dunia. Tanpa citra, seseorang akan berada dalam suasana yang tida pasti. Citra adalah gambaran tentang realitas dam tidak harus selalu sesuai dengan realitas. Dari kesepuluh klasifikasi citra yang dijabarkan oleh Boulding diatas, peneliti hanya menggunakan tiga sebagai acuan dalam penelitian ini. Ketiga klasifikasi citra yang dipilih ialah, citra tempat, citra waktu dan citra kesadaran atau ketidaksadaran. Citra tempat dipilih karena peneliti ingin melihat citra suatu kawasan wisata di KSN Cekungan Bandung melalui pandangan pengguna hastag \#explorebandung, pun sesuai dengan fokus utama dari penelitian ini. Selanjutnya pemilihan klasifikasi citra waktu karena peneliti ingin melihat perubahan citra dari wilayah KSN Cekungan Bandung dengan seiring berjalannya waktu. Dan yang terakhir, citra kesadaran atau ketidaksadaran peneliti pilih, karena peneliti ingin melihat hasil perilaku dari pengguna hastag \#explorebandung — baik itu secara sadar atau tidak - dalam kaitannya dengan citra KSN Cekungan Bandung. 
Paradigma yang digunakan dalam penelitian ini yaitu paradigma interpretatif. Penulis memandang bahwa penelitian mengenai citra KSN Cekungan Bandung dari sudut pandang pengguna hashtag \#explorebandung di Instagram ini merupakan suatu realitas sosial yang terbangun di khalayak Bandung berkat adanya new media. Paradigma interpretatif menurut Crotty, (dalam Gunawan 2015: 56) yaitu sebuah paradigma yang didasarkan pada keyakinan bahwa individu (manusia) merupakan makhluk yang secara sosial dan simbolik membentuk dan mempertahankan realita mereka sendiri.

\section{METODE PENELITIAN}

Pendekatan yang digunakan dalam penelitian ini adalah pendekatan kualitatif. Menurut Sugiyono (dalam Gunawan, 2015: 83), penelitian kualitatif mengkaji perspektif par-tisipan dengan strategi-strategi yang bersifat interaktif dan fleksibel. Penelitian ini bertujuan untuk memahami fenomena-fenomena sosial dari sudut pandang partisipan. Dengan demikian, penelitian kualitatif adalah penelitian yang digunakan untuk meneliti pada kondisi objek alamiah dimana peneliti merupakan instrumen kunci.

Penelitian kualitatif bermaksud menggali makna perilaku yang berada dibalik tindakan manusia. Interpretasi makna terhadap perilaku ini tidak dapat digali melalui verifikasi teori sebagai generalisasi empirik, seperti yang dilakukan pada penelitian kuantitatif(Gunawan, 2015 : 86). Dapat disimpulkan bahwa penelitian kualitatif merupakan jenis penelitian yang bertujuan untuk mendapatkan pemahaman yang mendalam mengenai masalah-masalah manusia dan sosial. Dalam penelitian kualitatif terdapat beberapa jenis metode, dan salah satu diantaranya yang digunakan dalam penelitian ini adalah metode deskriptif kualitatif.

Studi deskriptif kualitatif merupakan suatu penelitian yang mendeskripsikan atau menggambarkan sebuah fenomena secara sistematis sesuai apa adanya untuk menemukan informasi mengenai keadaan saat ini tanpa adanya kontrol perlakuan seperti yang dilakukan pada studi eksperimen sehingga cenderung tidak diarahkan untuk pengujian hipotesis, melainkan berusaha memaparkan keadaan yang sesungguhnya sesuai sebagai jawaban atas rumusan masalah yang diajukan (Dantes, 2012: 51). Penelitian deskriptif bertujuan untuk mengeksplorasi dan mengklarifikasi suatu fenomena atau kenyataan sosial, dengan cara mendeskripsikan sejumlah variabel yang berkenaan dengan masalah dan unit yang diteliti. Jenis penelitian ini tidak sampai mempersoalkan jalinan hubungan antarvariabel yang ada. (Ardianto, 2011: 48).

Pada akhirnya, penelitian deskriptif hanya memaparkan situasi atau peristiwa, tidak mencari atau menjelaskan hubungan, tidak menguji hipotesis atau membuat prediksi. Metode deskriptif dirancang untuk mengumpulkan informasi tentang keadaan-keadaan nyata yang sekarang berlangsung. Deskriptif ini digunakan untuk memperoleh pemahaman atau makna dibalik suatu kejadian dan digambarkan secara jelas bagaimana kejadian tersebut terjadi berdasarkan fakta yang ditemukan di lapangan untuk dicari jawaban atas permasalahan dan kemudian diteliti untuk ditarik kesimpulannya secara umum.

Objek penelitian ini adalah wisatawan pengguna hashtag \# explorebandung di Instagram. Wisatawan pengguna hashtag \#explorebandung di Instagram adalah mereka yang berwisata, mengunggah foto menggunakan Instagram dengan menambahkan hashtag \#explorebandung.

Metode pengumpulan data merupakan serangkaian teknik atau cara yang dapat digunakan seorang peneliti untuk mengumpulkan data. Teknik pengumpulan data dalam penelitian komunikasi, meliputi: kuisioner (angket), interview (wawancara), observasi (pengamatan), dokumentasi dan catatan pengalaman lapangan (Pujileksono, 2015: 120). Dalam penelitian ini penulis melakukan pengumpulan data dengan menggunakan metode wawancara mendalam dan observasi. Wawancara mendalam (intensive/ depth interview) adalah teknik mengumpulkan data atau informasi dengan cara bertatap muka langsung dengan informan agar mendapatkan data lengkap dan mendalam. Wawancara ini dilakukan dengan frekuensi tinggi (berulangulang) secara intensif. Sedangkan, observasi sendiri merupakan suatu teknik pengumpulan data yang dilakukan dengan cara mengadakan penlitian secara teliti (Arikunto, dalam Gunawan 2015: 143). Observasi yang digunakan adalah observasi tidak langsung. Observasi ini 
memungkinkan peneliti untuk mengumpulkan data secara tidak langsung di lapangan. Peneliti disini bertindak sebagai pengamat dan bukan pelaksana, selayaknya observasi langsung/partisipan Dalam penelitian ini, yang di observasi adalah perilaku dan percakapan yang terjadi diantara subjek yang diriset. Keunggulan penggunaan metode ini adalah daya yang dikumpulkan berbentuk perilaku dan percakapan. Selain itu, memungkinkan untuk mengamati perilaku nonverbal, juga mencakup perilaku verbal dari informan-informan yang ada.

Terdapat empat kriteria yang digunakan dalam menetapkan keabsahan data penelitian, yaitu (1) derajat kepercayaan (credibility), (2) keteralihan (transferability), (3) kebergantungan (dependability), dan (4) kepastian (confirmability). Uji validitas dan reliabilitas yang dilakukan oleh peneliti berdasarkan kriteria Kepercayaan atau Kredibilitas, yaitu mencakup dua hal, kecukupan bahan \& referensi dan triangulasi data (triangulasi sumber, triangulasi metode dan triangulasi waktu). Triangulasi data yang digunakan dalam penelitian ini yaitu triangulasi sumber dan triangulasi waktu.

Teknik analisis data yang digunakan dalam penelitian ini adalah metode analisis data model Miles dan Huberman. Pujileksono (205: 152) memaparkan bahwa analisis model ini dilakukan melalui tiga tahap yaitu: (1) Reduksi Data (Data Reduction). Reduksi data berarti merangkum, memilih hal yang pokok, memfokuskan pada hal yang penting, dicari pola dan temanya. Tahapan-tahapan reduksi data meliputi: Membuat ringkasan, Mengkode, Menelusur tema, Membuat gugusgugus, Membuat partisi, dan Menulis memo.,(2) Penyajian Data (Data Display). Penyajian data berarti mendisplay/menyajikan data dalam bentuk uraian singkat, bagan, hubungan antar kategori, dsb. Penyajian data yang sering digunakan dalam penelitian kualitatif adalah bersifat naratif, (3) Penarikan Kesimpulan dan Verifikasi (Conclusion Drawing and Verification). Kesimpulan dalam penelitian mungkin dapat menjawab rumusan masalah, karena rumusan masalah dalam penelitian kualitatif masih bersifat sementara dan berkembang setelah peneliti berada di lapangan. Kesimpulan penelitian kualitatif merupakan temuan baru yang disajikan berupa deskripsi atau gambaran yang awalnya belum jelas dan dapat berupa hubungan kasual/interaktif dan hipotesis/teori. Penarikan kesimpulan dan verifikasi dilakukan setelah dari lapangan.

\section{HASIL DAN PEMBAHASAN}

Bagian ini berisi penjelasan mengenai penelitian dan pembahasan yang bertujuan untuk mendapatkan pemahaman tentang citra Kawasan Strategis Nasional (KSN) Cekungan Bandung melaui Instagram. Penelitian ini dilakukan selama enam bulan, yaitu sejak September 2015 hingga Februari 2016.

Dalam enam bulan penelitian, peneliti menguraikan hasil perolehan pengumpulan data dengan menggunakan dua teknik pengumpulan data, yaitu wawancara mendalam dan observasi. Hasil wawancara peneliti paparkan dalam transkrip wawancara dan hasil observasi peneliti paparkan dalam catatan lapangan yang berguna untuk memperkaya data yang telah terkumpul.

Pemilihan informan dalam penelitian ini dilakukan dengan menggunakan teknik purposive, yang artinya informan dipilih atas pertimbangan dan tujuan tertentu. Selain itu, peneliti juga membuat kriteria khusus bagi para informan yang akan diteliti, yakni Informan berdomisili di wilayah Bandung atau pernah mengunjungi Bandung dalam kurun waktu setahun kebelakang, Informan telah dan aktif menggunakan Instagram selama dua tahun, Informan pernah menggunakan hashtag \#explorebandung dalam caption foto yang diunggah, minimal lima kali dalam sebulan terakhir terhitung semenjak Desember 2015, dan Informan bersedia untuk diwawancarai dan hasilnya dipublikasikan dalam penelitian ini.

Informan dalam penelitian ini dibagi menjadi dua jenis kriteria yaitu informan utama dan informan pendukung. Informan dalam penelitian ini berjumlah lima orang. Tiga informan utama terdiri dari seorang pendiri dari hashtag serta akun@explorebandung, seorang warga asli Bandung yang gemar menggunakan Instagram dan seorang wisatawan asal Bekasi yang sering menggunakan Instagram dan mengunjungi Bandung. Sedangkan dua informan pendukung merupakan seorang admin akun@ explorebandung dan seorang mahasiswa rantau 
yang berkuliah di Bandung.

Penelitian ini mendapatkan hasil setelah melalui dua tahap pengumpulan data yaitu dengan melakukan wawancara dan observasi. Wawancara dilakukan dalam rentang waktu dan tempat yang berbeda. Peneliti mengikuti keberadaan informan di manapun mereka berada, yaitu Kafe Roempi Bandung, KFC Grand Galaxy Park Bekasi, Cultivar Coffee House Bandung, Blue Doors Coffee Bandung, Retailpreneur Laboratorium FKB Telkom University Bandung.

Pengumpulan data observasi peneliti lakukan di dua tempat berbeda, yaitu Alun-alun Kota Bandung dan Bukit Moko. Pada Alun-alun Kota Bandung, peneliti berkesempatan untuk melakukan observasi ditengah-tengah kegiatan hunting foto yang dilakukan oleh salah satu informan peneliti yaitu Baiq. Sedangkan, pada Bukit Moko, peneliti melakukan observasi sendiri untuk meninjau langsung keberadaan tempat yang beberapa kali disebutkan oleh informan. Observasi dilakukan untuk mendapatkan data penunjang hasil wawancara yang lebih menitikberatkan pada keabsahan data yang diucapkan oleh informan. Hasil dari observasi ini diharapkan dapat memperkaya informasi dalam penyusunan hasil penelitian.

Wilayah KSN Cekungan Bandung sejak dahulu ternyata sudah memiliki beberapa sebutan yang membekas di masing-masing orang yang menetap maupun berkunjung ke wilayahnya. Ini terlihat dari beberapa pendapat yang berbeda mengenai citra KSN Bandung pada dahulu, seperti Ahmad Renaldi yang hidup 10 tahun dari musik, Bandung tidak lepas dari akan hal itu. Lain lagi jika melihat dari pandangan Iqbal yang notabene merupakan warga asli Bandung, yang mengatakan bahwa dahulu Bandung terkenal akan fashion dan kulinernya. Pendapat Iqbal pun didukung dengan penyataan dari Andre yang merupakan wisatawan asal Bekasi yang menyebutkan bahwa Bandung dahulu terkenal akan produk distro-nya (kaos, baju, dll). Tidak mengherankan jika beberapa merek distro lahir dan besar di Bandung, seperti Peter Says Denim, Smith, Ouval, RSCH dll. Disamping itu, ini juga dilihat dari keberadaan Jalan Cihampelas, Jalan Ir. H. Juanda dan Jalan Riau yang merupakan gudang dari wisata belanja di Bandung. Jalanjalan tersebut merupakan pusat-pusat belanja yang memiliki ragam distro maupun factory outlet.
Citra waktu yang terbentuk dari wilayah KSN Cekungan Bandung pada hari ini ialah menjadi salah satu tempat tujuan wisata yang lengkap dengan menawarkan berbagai jenis hiburan wisata, baik dari wisata alam, wisata kuliner hingga wisata belanja. Citra tersebut muncul dari masing-masing persepsi informan yang mengatakan bahwa Bandung kini sudah nyaman untuk dikunjungi karena banyak halhal baru yang dapat dieksplor. Selain itu juga Bandung pada hari ini seperti menunjukkan identitas wisatanya kepada siapapun melalui berbagai media, salah satunya adalah Instagram.

Citra kesadaran dan kesadaran ini muncul dari respon yang disampaikan para informan. Seluruhan informan menyampaikan responsnya masing-masing secara sadar, namun beberapa diantaranya tidak menyadari bahwa ia pada nyatanya sedang membantu citra KSN Cekungan Bandung ke arah yang lebih baik. Ini terlihat dari respon yang diperlihatkan oleh Ferrian. Saat itu ia bercerita secara sadar bahwa ia sedang mengurangi kebiasaan merokoknya jika ia berada di taman-taman kota. Ia melakukan hal tersebut atas dasar malu dan sebagai bentuk apresiasi terhadap kerja pemerintah yang sudah susah payah memperbaikinya. Dari situ terlihat bahwa ia secara tidak sadar membantu memperbaiki dan meningkatkan reputasi wilayah KSN Cekungan Bandung dengan mengurangi kebiasaan merokoknya di tempattempat umum.

KSN Bandung memiliki banyak citra yang terbentuk dari masing-masing informan. Ahmad Renaldi yang membanting tulang semenjak sepuluh tahun yang lalu di Bandung, melihatnya sebagai kota kreatif yang dimana semua hal ada di Bandung, baik itu dari tempat wisata alam, wisata belanja, wisata taman kota tematik, wisata kuliner hingga beragam pilihan tempat nongkrong bagi kawula muda. Tidak mengherankan jika kemudian Bandung dijuluki kota kreatif, karena banyak anak-anak muda hingga para dewasa muda yang merantau ataupun menetap di wilayah ini. Dengan belasan perguruan tinggi terkenal tak heran membuat Bandung menjadi ladangnya pemuda-pemudi di Provinsi Jawa Barat. Jumlah anak muda yang besar turut membuat citra Bandung menjadi lebih baik dari segi kreativitas, karena anak muda terkenal akan daya imajinasinya. Namun bagi para pendatang maupun wisatawan seperti 
Andre dan Baiq, citra tempat di Bandung bagi mereka masih berpusat pada bentangan alamnya. Andre yang berasal dari Bekasi mengaku senang dengan bentang alam Bandung, karena di tempat asalnya jarang ditemukan bentang alam hijau berbukit-bukit seperti di Bandung. Sama halnya dengan Andre, Baiq pun mengaku alam di Bandung masih oke untuk dikunjungi, karena di tempat asalnya jarang ditemukan pepohonan hijau yang rimbun dan teduhLombok merupakan salah satu pulau di Nusa Tenggara Barat yang beriklim tropis dengan cuaca cenderung lembab pantai.

Walau tiap informan menjelaskan dengan rinci citra tempat yang terbangun di benak mereka akan wilayah KSN Cekungan Bandung, namun penulis berhasil mengambil satu benang merah yang terjalin diantara mereka lewat ucapan dan respon yang dilontarkan olehmereka. Citra tempat yang kuat dari keseluruhan adalah bentang alamnya. KSN Cekungan Bandung patut bersyukur masih memiliki bentang alam yang terjaga keasriannya, sehingga hal tersebut dapat menjadi ujung tombak dalam memajukan pariwisata di wilayah ini.

Karakteristik Internet yang sangat fleksibel, memungkinkan para penggunanya untuk terus-menerus menembus batas-batas teknologi demi memperoleh manfaat maksimal sebelum akhimya dianggap aus, usang dan ditemukan teknologi baru yang lebih adaptif dalam menjawab tantangan jaman dan kebutuhan pengguna/komunitas (Hartoyo, 2015). Salah satunya adalah keberadaan media sosial Instagram. Instagram sendiri memiliki kegiatan "kopi darat" untuk para penggunanya saling berkumpul dan melakukan kegiatan hunting foto bersama. Kegiatan ini bernama Instameet. Selain itu Instagram juga memiliki kegiatan lain yang bernama WWIM atau Worldwide Instameet. WWIM ini merupakan pengembangan dari Instameet yang sebelumnya sudah dijelaskan, yang membedakan hanyalah cakupannya. Jika Instameet terbatas dalam lingkup wilayah tertentu, namun Worldwide Instameet cakupannya adalah global, dimana pada hari yang telah ditentukan Instagrammers di seluruh dunia berkumpul - di negara/ wilayahnya masing-masing, dan melakukan kegiatan hunting bersama.

WWIM tidak dilakukan pada satu tempat saja, namun tersebar di seluruh dunia. Biasanya WWIM digagas oleh para Instagrammers di wilayah-wilayah tersebut, dan pada hari yang telah ditentukan secara serentak mereka melakukan kegiatan hunting bareng dan mengunggahnya di Instagram dengan hashtag khusus. Karena memang berdasar pada suatu wilayah untuk tempat berkumpul dan hunting, tidak jarang WWIM ini diikuti dengan nama wilayahnya, seperti WWIM X Bandungartinya WWIM kesepuluh di Bandung.

Dari penyelenggaran Instameet dan WWIM, kegiatan yang benar-benar memberikan andil bagi citra KSN Cekungan Bandung adalah penyelenggaraan WWIM. Walau pada saat ini penyelenggaraan WWIM dianggap keluar jalur, namun hal tersebut tidak terjadi pada beberapa tahun sebelumnya yang memang ditujukan untuk kegiatan hunting foto bersama dan mengeksplor suatu wilayah secara serentak dalam hari dan waktu bersamaan. WWIM memiliki andil dalam citra KSN Cekungan Bandung karena pada tiap kali penyelenggaraan WWIM, terdapat satu hashtag wajib yang digunakan yaitu hashtag WWIM bersamaan dengan nama atau lokasi tempat penyelenggaraan WWIM itu berlangsung, seperti hashtag \#WWIMX_Bandung (dibaca WWIM ke-sepuluh Bandung). Dengan turut menyertakan nama wilayah atau lokasi tempat penyelenggaraan WWIM itu berlangsung, tentu hal tersebut akan memancing perhatian pengguna Instagram lain akan keberadaan wilayah tersebut, sehingga akhirnya gaung dari wilayah tersebut menjadi lebih terdengar dan terangkat.

Salah satu tempat di KSN Cekungan Bandung yang memiliki citra sangat kuat di kalangan para informan adalah Tebing Keraton. Tebing ini memiliki citra yang kuat karena masing-masing dari informan secara sadar menyebutkan keberadaan tempat ini pada penjelasan mereka ataupun sebagai contoh dari penjabaran mereka. Hampir seluruh informan pun pernah mengunjungi Tebing Keraton, sehingga tidak heran jika tebing tersebut memiliki citra yang sangat kuat.

Tebing Keraton sendiri ditemukan oleh pengguna hashtag \#explorebandung. Ia terletak di atas Taman Hutan Raya Ir. H. Juanda yang masih satu lokasi dengan lereng Gunung Tangkuban Perahu. Sejatinya, Tebing Keraton ini hanyalah tebing pada umumnya, yang menjorok keluar dari lerang, namun dengan 
paparan pepohonan yang membentang serta efek kabut yang terjadi menjelang pagi hari, menjadikan Tebing Keraton diperbaharui untuk menjadi salah satu atraksi wisata alam Cekungan Bandung.

Tebing Keraton sendiri merupakan sebuah tebing biasa yang menjorok dari daratan dengan pemandangan bukit-bukit komplek Taman Hutan Raya Ir. H. Juanda. Tebing Keraton ini, menurut Ahmad Renaldi dan Ferrian, ditemukan oleh anak-anak Instagram yang memang suka jalan-jalan dan mengeksplor sebuah wilayah-lebih lanjut disebut dengan anak-anak Explorebandung. Awalnya keberadaan tebing ini dirahasiakan terlebih dahulu oleh mereka, namun seiring berjalannya waktu akhirnya tebing ini terkuak ke masyarakat dan gaungnya masih terdengar hingga saat ini. Bahkan saat ini jalan yang dahulunya jelek dan berbatu kini sudah dipoles menggunakan cor, sudah terdapat lahan parkir bagi kendaraan bermotor dan sudah ditetapkan tarif retribusi untuk memasuki wilayah tebing ini. Intinya, Tebing Keraton sudah menjadi salah satu tempat tujuan wisata di KSN Cekungan Bandung.

Pada umumnya, orang-orang mengira citra hanya dimiliki oleh seseorang saja, atau mungkin di ranah ilmu komunikasi, citra hanya berkaitan dengan sebuah institusi atau organisasi. Namun lebih dari itu, kini citra sudah melingkupi hampir semua aspek yang ada di dunia. Mulai dari citra sebuah merek, sebuah benda mati, sebuah acara, hingga sebuah tempat. Oleh karena itu penelitian ini mengangkat citra sebuauh tempat, karena erat kaitannya sebuah tempat dengan dinamika kehidupan yang terjadi didalamnya.

Peneliti sendiri mengambil keberadaan hashtag serta akun@explorebandung sebagai batasan dalam meneliti, karena peneliti melihat hashtag serta akun ini yang benar-benar merepresentasikan citra secara maya dari wilayah KSN Cekungan Bandung itu sendiri. Mungkin ada hashtag maupun akun yang serupa dengan Explorebandung, namun mereka tidak secara spesifik menampilkan foto-foto bidikan wilayah Bandung. Lagi pula, jika kata "Explorebandung" dipecah menjadi dua kata utama yaitu "explore"_-jika diartikan menjadi eksplor, dan "bandung", ini berarti hashtag dan akun ini memang ditujukan untuk menampilkan hasil-hasil foto eksplorasi wilayah-wilayah di
KSN Cekungan Bandung. Selanjutnya, perihal pemilihan pengguna hashtag \#explorebandung sebagai objek dalampenelitian ini, karenapeneliti berasumsi mereka yang menggunakan hashtag tersebut memang suka untuk mengeksplorasi tempat-tempat yang ada di Bandung.

Kembali berbicara mengenai citra, jika diartikan citra memiliki pengertian sebagai serangkaian pengetahuan, pengalaman, perasaan (emosi) dan penilaian yang diorganisasikan dalam sistem kognisi manusia; atau pengetahuan pribadi yang sangat diyakini kebenerannya (Ardianto, 2011: 98). Citra ini terbentuk dengan tidak secara instan. Ia terbentuk dari stimulus dan pengalaman seseorang dalam menghadapi suatu hal, sehingga output yang dihasilkan berupa respon dapat berbeda-beda satu sama lain. Boulding (dalam Ardianto, 2009: 26) membagi citra menjadi sepuluh klasifikasi yang berbeda, yaitu: (1) Citra ruang/tempat, (2) Citra waktu, (3) Citra rasional, (4) Citra perorangan, (5) Citra nilai, (6) Citra emosional, (7) Citra kesadaran atau ketidaksadaran, (8) Citra keyakinan atau ketidakyakinan, (9) Citra dalam dimensi realitas dan bukan realitas bahwa citra berkaitan dengan dunianya dengan sesuatu diluar realitas, serta, dan (10) Citra yang bersifat umum, yaitu citra pribadi yang sesuai dengan citra yang ditunjukkan oleh kehendak orang lain.

Dalam penelitian ini, peneliti hanya mengambil tiga dari sepuluh klasifikasi yang ada, yaitu citra ruang/tempat, citra waktu dan citra kesadaran \& ketidaksadaran. Peneliti memilih tiga klasifikasi tersebut bukan tanpa sebab, karena peneliti meyakini hanya ketiga jenis itulah yang dapat menggambarkan citra dari wilayah KSN Cekungan Bandung dengan objek penelitian para pengguna hashtag \#explorebandung.

Citra ruang/tempat yang muncul dari perspektif pengguna hashtag \#explorebandung mengenai KSN Cekungan Bandung ialah sebuah wilayah yang memiliki keberagaman jenis tempat, seperti bentang alam, tamantaman kota, tempat-tempat nongkrong/kafe dan hal-hal menarik lainnya. Kota yang serba ada, begitu gambaran dari Mang Pew dan Ferrian saat ditanya mengenai citra dari KSN Cekungan Bandung. Walaupun begitu, tetap ada satu hal yang menonjol dari semua hal menarik yang ada di wilayah ini, dan satu hal ini juga terucap oleh kelima informan yang sama- 
sama menggunakan hashtag \#explorebandung, yaitu bentang alam yang tersaji hampir di seluruh area KSN Cekungan Bandung. Tidak mengherankan jika seluruh informan menyebut alam sebagai citra tempat/ruang dari KSN Cekungan Bandung, karena memang letak KSN Cekungan Bandung itu sendiri yang berada di daerah dataran tinggi. KSN Cekungan Bandung sendiri dikelilingi oleh gunung-gunung hingga perbukitan disekelilingnya sehingga kemudian wilayah ini dinamakan Cekungan Bandung.

Citra waktu berpusat pada perubahanperubahan yang terjadi pada suatu hal yang menyangkut kredibilitas hal tersebut, seiring dengan berjalannya waktu. Pada mulanya peneliti akan mencoba menjabarkan citra waktu beberapa tahun yang lalu dari KSN Cekungan Bandung dan kemudian akan dilanjutkan dengan menjabarkan citra KSN Cekungan Bandung pada saat ini. Citra waktu yang dimunculkan pada KSN Cekungan Bandung pada beberapa tahun yang lalu yakni salah satu pusat fashion di Indonesia. Ini ditegaskan oleh Andre selaku wisatawan dari Bekasi, yang mengaku dahulu ia mengetahui Bandung hanya sebatas "tempat beli baju", "tempat beli kaos" ataupun "gudangnya distro-distro". Begitupun dengan apa yang diutarakan Mang Pew dan Iqbal yang sudah lama tinggal dan menetap di wilayah Bandung. Mereka menyebut Bandung sebagai kota fashion di Indonesia. Tidak mengherankan jika informan berkata demikian, karena memang tersebar pusat-pusat perbelanjaan di wilayah KSN Cekungan Bandung, seperti Paris Van Java di Kota Bandung, Cimahi Supermall di Kota Cimahi dan Jatinangor Town Square di Kabupaten Sumedang. Selain memang keberadaan pusat-pusat perbelanjaan tersebut, predikat kota fashion begitu melekat di Bandung dengan adanya dua jalan utama yang hampir seluruh tokonya berjualan produk fashion, yaitu Jalan Cihampelas dan Jalan L.L.R.E Martadinata - dikenal juga dengan sebutan Jalan Riau. Jika Cihampelas terkenal akan ragam distro, berbeda dengan kawasan Riau yang terkenal akan jajaran factory outletnya. Beberapa merek clothing terkenal lahir dari Bandung, seperti Peter Says Denim, Ouval Research, Unk1347 dan 3SECOND. Belum lagi sederetan factory outlet terkenal sepanjang jalan L.L.R.E Martadinata dan beberapa di jalan Ir. H. Juanda. Tak heran jika dahulu KSN Cekungan
Bandung memiliki citra sebagai kota mode di Indonesia.

Melangkah ke depan, citra waktu yang diperlihatkan oleh KSN Cekungan Bandung pada hari ini adalah wilayah tujuan wisata. Ini disebabkan dengan munculnya beragam atraksi wisata yang ada di KSN Cekungan Bandung. Jika mindset orang-orang dahulu ke Bandung hanya untuk memuaskan hasrat berbelanja saja, namun kini orang-orang ke Bandung lebih dari sekedar berbelanja. Banyak dari mereka yang mengunjungi tempat-tempat wisata di Bandung, seperti halnya Andre danAnetyang mengunjungi Tebing Keraton. Bahkan Andre sendiri mengaku berminat untuk mengunjungi Bandung lagi jika memang suatu saat akan ada hal baru yang bisa dikunjungi di Bandung. Sedangkan untuk warga Bandungnya sendiri, mereka sangat terbantu dengan dibukanya ragam tempat publik untuk mereka bersosialiasai. Iqbal yang tumbuh dan besar di Bandung melihat kampung halamannya kini seperti saat ia kecil dahulu, salah satunya yang benar-benar ia rasakan adalah pengadaan taman-taman. Jika dahulu taman-taman hadir dengan ala kadarnya, namun sekarang tamantaman tersebut muncul kembali dengan tematema yang unik dan menarik guna merangsang warga untuk datang mengunjunginya. Salah satu taman di wilayah KSN Cekungan Bandung yang baru diperbaharui dan diresmikan oleh otoritas setempat belakangan ini adalah Taman Teras Cikapundung.

Tentu saja keberadaan citra tempat dan citra waktu yang berubah-ubah tidak lepas dari satu sosok fenomenal ini. Kelima informan menyebut satu nama ini sebagai salah satu dalang dibalik kepopuleran KSN Cekungan Bandung. Adalah seorang Ridwan Kamil yang berhasil membawa - tidak hanya citra kota Bandung itu sendiri namun juga citra KSN Cekungan Bandung pada umumnya — menjadi lebih baik. Terlebih ia benar-benar paham bagaimana menggunakan Instagram sebagai salah satu saran penyalur informasi dan interaksi dengan warganya. Banyak hal yang ia unggah pada laman Instagram pribadinya tersebut. Beberapa kali ia mengunggah rancangan kerjanya, beberapa kali pula ia mengunggah potret diri atau keluarganya, dan tidak sedikit pula ia mengunggah hasil kerjanya.

Salah satu foto unggahan terbarunya tersebut memperlihatkan rancangan kerjanya 

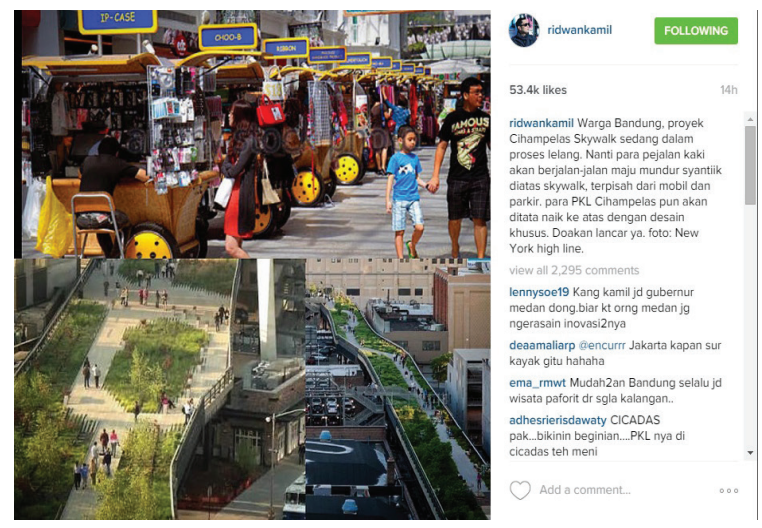

Sumber: Instagram Ridwan Kamil, 2016

\section{Gambar 1 Foto Unggahan Ridwan Kamil}

di masa yang akan datang, yaitu pembangunan pedestrian melayang di jalan Cihampelas.

Dengan menunjukkan foto hasil kerja maupun rancangan kerja tersebut ke Instagram pribadi-nya, hal ini tentu membuat antusias warga dan followers-nya meningkat. Selain itu juga akan berdampak pada meningkatnya awareness masyarakat akan lingkungan tempat mereka tinggal. Dengan adanya tempat-tempat baru membuat masyarakat sadar untuk menjaga kelangsungan tempat tersebut. Hingga pada akhirnya muncul hashtag \#nuhunkangemil sebagai salah satu bentuk apresiasi masyarakat di media sosial untuk seorang Kang Emilsapaan akrab Ridwan Kamil. Penyaluran informasi yang baik dari pemimpin kepada warganya dengan menggunakan media sosial, dan diapresiasi dengan baik pula oleh warganya akan berdampak pada kualitas citra wilayah tersebut. Inilah yang terlihat dari KSN Cekungan Bandung pada saat ini. Dimulai dari pemimpinnya hingga warganya bersatu padu membuat kondisi wilayah yang nyaman untuk diri mereka sendiri maupun bagi para pendatang.

Selanjutnya yang akan dibahas adalah citra kesadaran \& ketidaksadaran. Klasifikasi citra ini muncul dari respons yang diperlihatkan seseorang dalam menyikapi suatu hal, baik itu ia sadari atau tidak. Berbagai macam respon diungkapkan para informan secara sadar maupun tidak disadari. Citra KSN Cekungan Bandung yang muncul dari klasifikasi ini ialah ramai, gaul/asyik, dan setiap tempat memiliki ceritanya masing-masing. Citra wilayah yang ramai dan gaul muncul dari Anet yang secara sadar merasakan hal tersebut. Sebelum ia menginjak Bandung, ia mengira bahwa Bandung itu tidak terlalu ramai dengan tingkat keramaian yang normal layaknya keramaian di kotanya dahulu. Setelah ia sampai di Bandung, barulah ia menyadari bahwa wilayah ini amatlah ramai dengan beragam jenis kehidupan di dalamnya. Baik Anet maupun Andre - sebagai informan dari sudut pandang pendatang atau wisatawanmelihat Bandung sebagai wilayah yang asyik untuk dieksplor lebih jauh. Sedangkan untuk Iqbal dan Ferrian yang merupakan warga asli Bandung, beberapa tempat di Bandung memiliki cerita tersendiri bagi mereka sehingga secara tidak sadar mereka benar-benar menikmati waktu mereka saat di tempat tersebut. Dilihat dari respons yang mereka ungkapkan, secara tidak sadar mereka membentuk persepsi di benak mereka masing-masing akan citra KSN Cekungan Bandung, walau tidak sedikit dari mereka yang menceritakannya kembali pada peneliti.

\section{Tabel 1 Citra KSN Cekungan Bandung}

\begin{tabular}{|c|c|c|c|}
\hline No. & $\begin{array}{c}\text { Klasifikasi } \\
\text { Citra }\end{array}$ & Citra & $\begin{array}{l}\text { Komponen } \\
\text { Pendukung }\end{array}$ \\
\hline 1. & Citra Tempat & $\begin{array}{l}\text { Memiliki beragam } \\
\text { jenis tempat, } \\
\text { mayoritas bentang } \\
\text { alam. }\end{array}$ & \multirow{3}{*}{$\begin{array}{c}\text { Ridwan } \\
\text { Kamil }\end{array}$} \\
\hline \multirow{2}{*}{2.} & \multirow{2}{*}{ Citra Waktu } & $\begin{array}{c}\text { Sebelum - pusat } \\
\text { fashion }\end{array}$ & \\
\hline & & $\begin{array}{c}\text { Sesudah - tujuan } \\
\text { wisata }\end{array}$ & \\
\hline 3. & $\begin{array}{l}\text { Citra } \\
\text { Kesadaran \& } \\
\text { Ketidaksadaran }\end{array}$ & $\begin{array}{l}\text { Ramai, gaul } \\
\text { dan tiap tempat } \\
\text { memiliki cerita } \\
\text { masing-masing } \\
\text { bagi yang } \\
\text { mengunjunginya }\end{array}$ & - \\
\hline
\end{tabular}

Sumber: M. Christin, A. Prasetio \& R. P. Perdana, 2016

Di samping memang suka mengeksplor tempat-tempat di wilayah KSN Cekungan Bandung secara mandiri, beberapa dari informan juga sering melibatkan diri untuk ikut kegiatan hunting bersama yang diselenggarakan oleh Instagram yaitu Instameet ataupun Worldwide Instameet (WWIM). Instagram dalam bukunya yang berjudul History of Instagrammenyebutkan definisi Instameet sebagai berikut:

"Connecting online and in the real world. Since the earliest days of Instagram, people have been meeting up offline and forming relationships in the real world. The forms that Instameets take are as diverse as the community in which they exist. They can rekindle an appreciation 
for one's town or city, provide an excuse to explore someplace new with a friend or offer an opportunity to connect with locals while traveling aboard. In a community where people inspire and share moments with one another, Instameets offer another opportunity to connect, whether it be to exchange photo-taking tips or share a great spot to capture the last bit of light at dusk." (Christin, Prasetio \& Perdana, 2016)

Sedang Worldwide Instameet memiliki pengertian yang lebih singkat, padat dan jelas, yakni sebagai berikut:

"Instameets occur organically all across the globe at any given time. Several times a year, however, Instagram will encourage people to synchronize their meet-ups for a Worldwide Instameet, and organizers around the world will put out the call to their local Instagrammer communities."

Jika pengertian Instameet dan WWIM seperti itu, beda halnya dengan apa yang diutarakan oleh beberapa informan. Ahmad Renaldi dan Ferrian kini melihat keberadaan Instameet dan WWIM tidak lagi sebagai ajang pertemuan para Instagramers, namun sudah mengerucut menjadi sebuah aktivitas guna memperkenalkan suatu merek tertentu. Bagi mereka yang memang mengikuti Instameet atau WWIM guna memperluas jaringan dan memperkaya wawasan mereka akan fotografi, pasti akan merasa kecewa dengan kehadiran bentuk Instameet/WWIM seperti itu. Namun disisi lain, kegiatan Instameet/WWIM yang bertujuan untuk mengaktivasi sebuah merek juga salah satu bentuk kreatif dari orang-orang yang berkecimpung didalamnya.

Kegiatan WWIM sendiri merupakan salah satu kegiatan utama Instagram yang acara utamanya adalah hunting foto bersama secara serentak dengan cakupan peserta secara global. Explorebandung sendiri telah mencetak rekor sebanyak tiga kali dalam menyelenggarakan kegiatan WWIM di wilayah KSN Cekungan Bandung, yaitu WWIM ke-9 pada tahun 2012, WWIM ke-10 pada tahun 2013, dan WWIM ke-11 pada tahun 2014. Pada tahun 2015, Explore Bandung tidak menyelenggarakan
WWIM karena menurut Mang Pew selaku founder mengatakan bahwa penyelenggaran WWIM saat itu sudah tidak tepat sasaran. Dari ketiga WWIM yang dilaksanakan oleh Explorebandung, Mang Pew mengaku terkejut dengan jumlah peserta yang mencapai 1000an lebih pada saat WWIM ke-10 di GOR Saparua. Melihat antusiasme yang begitu besar, Mang Pew dan Ferrian-yang kala itu ikut menjadi salah satu peserta Worldwide Instameet - setuju bahwa WWIM dapat meningkatkan citra KSN Cekungan Bandung itu sendiri. Ini dilihat dari semakin tereksposnya tempat-tempat yang luput dari perhatian warga ataupun wisatawan dan dengan pengunggahan foto secara serentak ke Instagram dengan menggunakan hashtag \#explorebandung yang saat itu merupakan hashtag wajib bagi para peserta WWIM. Dengan hasil-hasil foto hunting bersama saat WWIM dan diunggah di Instagram, tentu membuat wawasan pengguna Instagram lainnya menjadi lebih luas. Tentu citra KSN Cekungan Bandung dengan keberagaman tempat wisata menjadi lebih kuat kedepannya.

Salah satu tempat di KSN Cekungan Bandung yang memiliki citra sangat kuat di kalangan para informan adalah Tebing Keraton. Tebing ini memiliki citra yang kuat karena masing-masing dari informan secara sadar menyebutkan keberadaan tempat ini pada penjelasan mereka ataupun sebagai contoh dari penjabaran mereka. Hampir seluruh informan pun pernah mengunjungi Tebing Keraton, sehingga tidak heran jika tebing tersebut memiliki citra yang sangat kuat. Tebing Keraton sendiri merupakan sebuah tebing biasa yang menjorok dari daratan dengan pemandangan bukit-bukit komplek Taman Hutan Raya Ir. H. Juanda. Tebing Keraton ini, menurut Mang Pew dan Ferrian, ditemukan oleh anak-anak Instagram yang memang suka jalan-jalan dan mengeksplor sebuah wilayah-lebih lanjut disebut dengan anak-anak Explorebandung. Awalnya keberadaan tebing ini dirahasiakan terlebih dahulu oleh mereka, namun seiring berjalannya waktu akhirnya tebing ini terkuak ke masyarakat dan gaungnya masih terdengar hingga saat ini. Bahkan saat ini jalan yang dahulunya jelek dan berbatu kini sudah dipoles menggunakan cor, sudah terdapat lahan parkir bagi kendaraan bermotor dan sudah ditetapkan tarif retribusi untuk memasuki wilayah tebing 
ini. Intinya, Tebing Keraton sudah menjadi salah satu tempat tujuan wisata di KSN Cekungan Bandung.

Setelah ditelaah lebih jauh ternyata masingmasing informan tidak pernah membatasi diri mereka untuk mengunjungi suatu tempat yang kemudian diabadikan dalam bentuk foto. Mereka memang update tentang tempat-tempat terbaru di wilayah KSN Cekungan Bandung, namun kembali lagi, tidak peduli tempat tersebut baru, lama, mainstream ataupun populer, selama mereka nyaman untuk mengambil foto di tempat tersebut mereka akan mendatanginya. Mereka lebih percaya kepada intuisi mereka dalam mengabadikan sebuah momen di sebuah tempat. Tak heran jika mereka dapat mengolah foto menjadi lebih menarik dari sebuah tempat yang biasa-biasa saja, dan itu pun tentu bermain-main dengan sudut pengambilan yang tidak biasa.

\section{SIMPULAN}

Setelah peneliti mengumpulkan data-data semenjak pra-penelitian, lalu melakukan penelitian dengan menggunakan wawancara mendalam dan observasi, yang kemudian diakhiri dengan melakukan analisis data, maka dapat ditarik kesimpulan dalam penelitian yang berjudul Citra Kawasan Strategis Nasional (KSN) Cekungan Bandung Melalui Instagram (Studi Deskriptif pada Pengguna Hashtag \#explorebandung) ialah sebagai berikut:

Bentuk kegiatan yang dilakukan oleh pengguna hashtag \#explorebandung dalam keterkaitannya akan citra KSN Cekungan Bandung adalah dengan mengikuti kegiatan Worldwide Instameet (WWIM). WWIM sendiri merupakan bentuk kegiatan hunting foto bersama dengan cakupan peserta secara global yang diprakarsai oleh media sosial Instagram. WWIM diselenggarakan di seluruh dunia, termasuk di Indonesia. Untuk di wilayah KSN Cekungan Bandung sendiri, salah satu pelopor sekaligus penyelengga WWIM adalah Explorebandung. Explore bandung telah menyukseskan tiga kali penyelenggaraan WWIM yang dimulai pada tahun 2012 hingga terakhirpadatahun2014. Menurutparainforman, terutama Mang Pew, Iqbal dan Ferrianketiganya merupakan warga Bandung, kegiatan semacam WWIM ini memiliki manfaat bagi citra wilayah KSN Cekungan Bandung. Salah satu manfaatnya adalah semakin dikenalnya wilayah KSN Cekungan Bandung sebagai salah satu wilayah penyelenggaraan WWIM. Patut diketahui bahwa output dari penyelenggaraan kegiatan ini selain untuk mempertemukan para pengguna Instagram itu sendiri, namun juga hasil-hasil foto yang diunggah ke Instagram. Dengan begitu, foto-foto yang menampilkan sudut wilayah KSN Cekungan Bandung akan dilihat oleh banyak orang dan tentu hal itu akan meningkatkan wawasan serta citra KSN Cekungan Bandung di masyarakat luas, bahwa KSN Cekungan Bandung tidak sebatas tempattempat mainstream pada umumnya.

Citra KSN Cekungan Bandung secara garis besar dilihat dari data-data yang terangkum dalam penelitian ini dan setelah melalui tahapan analisis data, dapat dinyatakan bagus dan positif. Guna memudahkan penentuan citra dari wilayah ini, peneliti menggunakan tiga klasifikasi citra yaitu citra tempat/ruang, citra waktu dan citra kesadaran \& ketidaksadaran. Citra tempat yang muncul dari perspektif pengguna hashtag \#explorebandung mengenai KSN Cekungan Bandung ialah wilayah yang memiliki keberagaman jenis tempat dan salah satu yang menonjol adalah dari sisi bentang alamnya. Tidak dapat dipungkiri bahwa wilayah KSN Cekungan Bandung yang berada didaerah dataran tinggi sehingga banyak tempat-tempat yang pada mulanya bukan tempat apa-apa namun sekarang menjadi incaran wisatawan maupun warga Bandung itu sendiri. Tebing Keraton, Bukit Moko, Bukit Cukul Pangalengan adalah beberapa contohnya. Selanjutnya adalah citra waktu. Citra waktu yang diperlihatkan dari KSN Cekungan Bandung ialah wilayah tujuan wisata. Ini dapat dilihat dari menjamurnya tempat-tempat wisata, baik alam, sejarah, kuliner maupun fashion di wilayah KSN Cekungan Bandung. Ini pertanda baik karena hal tersebut akan mengundang animo masyarakat luar untuk datang ke Bandung. Terakhir adalah citra kesadaran \& ketidaksadaran. Citra yang muncul dari klasifikasi ini memperlihatkan bahwa KSN Cekungan Bandung merupakan sebuah wilayah yang ramai, gaul dan berisikan tempattempat yang memiliki ceritanya masing-masing. Citra ini muncul atas kesadaran dari masingmasing informan dalam menggambarkan KSN Cekungan Bandung, dan memang begitulah 
adanya yang terjadi di lapangan.

Berbagai tempat disebutkan oleh masingmasing informan. Mulai dari yang terkenal hingga yang awam terdengar. Dari keseluruhan tempat yang disebutkan, Tebing Keraton menjadi tempat yang diucapkan beberapa kali dari keseluruhan informan. Tidak ada informan yang tidak mengucapkan tempat ini dalam penjelasannya, dan tidak ada informan yang tidak pernah mengunjungi tempat ini. Tidak mengherankan jika tempat ini menjadi salah satu tempat yang sering diucapkan oleh para informan dalam menjelaskan informasinya mengenai citra cekungan Bandung, karena tempat ini memang pada mulanya ditemukan oleh pengguna hashtag \#explorebandung itu sendiri. Tebing ini memiliki citra yang kuat - serta berkaitan dengan citra tempat — karena keberadaannya yang masih asri dan jauh dari hiruk pikuk kota.

Setelah dilakukannya penelitian ini hingga terakhir, terdapat beberapa saran yang peneliti berikan sebagai berikut: (1) Saran Akademis. Selama dilakukannya penelitian ini terdapat keterbatasan yang peneliti alami, salah satunya temuan penelitian mengenai citra tempat/ wilayah/ kota. Dikarenakan belum banyak akademisi ilmu komunikasi yang mengangkat tema citra tempat/ wilayah/ kota sebagai penelitian tingkat akhir. Untuk selanjutnya, penelitian serupa dapat dilakukan dengan menggunakan daerahdaerah lain di Indonesia guna meningkatkan kepedulian masyarakat sekitar akan citra tempat tinggal mereka. Selain itu juga untuk memperkaya informasi untuk penelitianpenelitian lain kedepannya (2) Saran Praktis. Setelah mengetahui kesimpulan dari penelitian ini, hasilnya dapat diserahkan kepada pemerintah-pemerintah lokal di wilayah KSN Cekungan Bandung untuk semakin giat membangun citra wilayah ini dengan saling berintegrasi satu sama lain. Tidak hanya itu, hasil penelitian ini juga dapat dijadikan referensi bagi pemerintah kita untuk mulai fokus dengan memanfaatkan media sosial sebagai sarana membangun citra, menyampaikan informasi publik dan berinteraksi langsung dengan warga. Adapun saran praktis untuk simpulan hasil penelitian dan pembahasan diatas ialah:

Perihal penyelenggaran Worldwide Instameet di wilayah KSN Cekungan
Bandung. Penulis mengharapkan bahwa pada kemudian hari bisa terbentuk sebuah sinergi dan kolaborasi yang kuat antara pelaku kreatif di wilayah KSN Cekungan Bandung dengan otoritas setempat dalam menyelenggarakan WWIM ini. Dilihat dari hasil penelitian yang menyimpulkan bahwa ada dampak positif yang ditimbulkan dari penyelenggaraan WWIM sebelumnya baik dari Instagrammers di Bandung maupun otoritas setempat bekerja sama untuk terus meningkatkan citra positif KSN Cekungan Bandung melalui acara-acara kreatif seperti ini.

Perihal citra yang ditampilkan KSN Cekungan Bandung pada saat ini, penulis menyarankan untuk otoritas setempat lebih dapat berbaur dengan masyarakat, tak ketinggalan ialah komunitas-komunitas kreatif. Ini dimaksudkan untuk secara bersama-sama mempertahankan citra yang sudah baik, bahkan jika memungkinkan untuk terus meningkatkan citra yang sudah baik.

Perihal keberadaan tempat-tempat yang dijadikan spot foto para Instagrammers yang mengunjungi wilayah KSN Cekungan Bandung, penulis menyarankan untuk pemerintah setempat untuk segera memfasilitasi tempat tersebut dengan lebih layak. Salah satu cara termudahnya ialah dengan turut memberdayakan masyarakat sekitar akan pentingnya tempat-tempat tersebut sebagai citra dari wilayah KSN Cekungan Bandung. Dengan diedukasikannya masyarakat sekitar, tentu hal tersebut akan mendorong mereka untuk lebih peduli menjaga tempat tersebut.

\section{DAFTAR PUSTAKA}

Ardianto, E. (2011). Metodologi penelitian untuk public relations kuantiatif dan kualitatif. Bandung: Simbiosa Rekatama Media.

Azalea, N. Rise, C \& Valle, P. D. (2012). History of instagram. San Fransisco: Instagram.

Boulding, K. (1956). The image. Ann Arbor: University of Michigan Press.

Croteau, D. \& Hoynes, W. (2003). Media/ 
society: industries, images, and audiences. Thousan: Pine Forge Press.

Christin, M., Prasetio, A., \& Perdana, R. P. (2016). The Image of bandung basin National Strategic through Instagram. Heritage, culture, and society: research agenda and best practices in the hospitality and tourism industry. London, UK: Taylor \& Francis Group. Diakses dari https://books.google. co.id/

Dantes, N. (2012). Metode penelitian. Yogyakarta: ANDI.

Ditjen Mineral dan Batubara. (2008). Lembaran Negara Republik Indonesia: Peraturan Pemerintah Republik Indonesia Nomor 26 Tahun 2008 Tentang Rencana Tata Ruang Wilayah Nasional. Diakses dari: https: //www. minerba.esdm.go.id/library/sijh/pp262008.pdf

Fikri, A. (2015). Tata ruang bandung raya bakal diatur lewat perpres. Diakses dari: http: //nasional.tempo.co/read/ news/2015/11/13/058718711/tataruang-bandung-raya-bakal-diaturlewat-perpres
Gunawan, I. (2015). Metode penelitian kualitatif. Jakarta: Bumi Aksara.

Hartoyo, N. M. \& Supriadi, D. (2015). Aktivisme sosial melalui penggunaan media sosial: studi kasus asosiasi ibu menyusui indonesia (AIMI). Jurnal Kajian Komunikasi, Vol.3 (1), 1-11.

Kamil, R. (2016). Ridwan kamil. Diakses dari https://www.instagram. $\mathrm{com} / \mathrm{p} / \mathrm{BCDLPavuKbg/?taken-}$ by $=$ ridwankamil

Pujileksono, S. (2015). Metode penelitian komunikasi kualitatif. Malang: Intrans Publishing.

Salamah, U. \& Yananda, M. R. (2014). Branding tempat: membangun kota, kabupaten dan provinsi berbasis identitas. Jakarta: Makna Informasi.

Somad, R. \& Priansa, D.J.(2014).Manajemen komunikasi: mengembangkan bisnis berorientasi pelanggan. Bandung: Alfabeta.

Vivian, J. (2008). Teori komunikasi massa. Bandung: Prenada Media Group.

West, R., \& Turner, L. H. (2008). Pengantar teori komunikasi analisis dan aplikasi buku 2. Jakarta: Salemba Humanika. 